\title{
THE NEEDS OF YOUTH AND SPATIAL JUSTICE. HOW THE INCLUSION OF YOUTH PREFERENCES CAN SUPPORT TARGETED REGIONAL POLICIES
}

\author{
Przemysław Kulawczuk (D), Andrzej Poszewiecki (D), Adam Szczęch (D) \\ Faculty of Economics, University of Gdańsk \\ Armii Krajowej 119, 81-824 Sopot: Poland \\ przemyslaw.kulawczuk@ug.edu.pl• andrzej.poszewiecki@ug.edu.pl•adam.szczech@ug.edu.pl
}

\begin{abstract}
Euroregion Baltic faces strong depopulation pressure, with Poland and Lithuania both experiencing marked population declines, especially in rural areas, in the last 20 years - thanks to immigration abroad. Internal immigration to these countries' cities is also taking place. While Germany, Sweden, Russia and Denmark have achieved temporary improvements in population indicators, this was thanks to their willingness to take in war refugees - a factor therefore incidental in nature, and not impacting upon an overall trend seeing people move out of rural areas in large numbers. With a view to this challenge being addressed in a more permanent way, research described here assessed whether the introduction of youth-policy measures might allow for better revamping of regional policies so as to persuade young people to remain in their regions. An assumption underpinning this work was that departure from a region reflects deficits in spatial justice, first and foremost an unequal distribution of infrastructure vis-à-vis education, housing, recreation, jobs, and so on. To determine which spheres critically underpin a decision to leave, young people's preferences for their futures were studied under the CASYPOT project, involving 6 localities in four of the Euroregion's states. In the event, the research was able to confirm a capacity on the part of youth surveys to deliver information on factors critical to decision-making that can be regarded as of value as regional policies are reorientated to try and ensure a higher level of spatial justice. The survey showed that factors most likely to prompt out-migration among young people relate to insufficient educational services and the inadequacy of the labour market. Beyond that, personal (e.g. marriage-related) issues play a role, as do leisure activities. Overall, general economic interest services are confirmed as playing a key role in shaping young people's decisions to migrate out of an area.
\end{abstract}

Keywords: migration, policy change management, regional policy, spatial justice, youth policy, youth survey.

\section{Introduction and the problem formulation}

The work detailed here relates to what is called Euroregion Baltic (ERB), i.e. a voluntary cooperation agreement pertaining between units of regional administration located by the Baltic Sea, in Poland (the Pomerania and Warmia-Mazury regions), Sweden (Counties of Kalmar, Blekinge, Kronoberg and Skania), Lithuania (Klaipeda District), Russia (Kaliningrad District), and Denmark (Bornholm District). It was within the ERB framework that the CASYPOT project provided for research into youth welfare pursued in the years 2016-2019².

${ }^{1}$ CASYPOT - Capacity Building for Strategic Youth Policy and Transnational Cooperation - is an international project, led by Kalmar County in Sweden, in collaboration with partners from elsewhere in Sweden, as well as Lithuania, Russia and Poland. The aim has been partnerly exchange of skills and knowledge on how strategic youth policies might be better devised and pursued (see: casypot.eu). 
The main challenge facing this Euroregion is depopulation, especially in peripheral areas and where the younger generation is concerned. For the purposes of the work detailed here, the phenomenon is deemed to reflect dysfunction in the provisioning of spatial justice, as manifested in glaring disparities in the distribution of regional infrastructure as regards education, work, housing, recreation, etc. Ultimately, the work had as its objective verification as to how far youth policy might represent a useful source of knowledge input as regional-policy tools are being applied to regenerate depopulated areas.

The main problem addressed here is thus a gap in our knowledge as to young people's propensities to leave or remain in their own peripheral (rural, provincial) home towns, to the extent that concrete decisions regarding out-migration may later arise. The propensities in question are viewed in relation to young people's life-visions, motivations and plans for the future, as all capable of influencing their lives, including when it comes to decisions to migrate. While the literature on migration among young people is indeed very extensive, little has been done to understand what the role of life plans might be, in regard to professional and free-time mobility. The CASYPOT research referred to goes at least some way to filling this evident gap, looking at future plans among young people in 6 selected municipalities in four of the ERB member states. Further analysis considered whether public (e.g. youth-related or regional) policy is in a position to address the explored needs of young people, deploying relevant tools to influence (i.e. reduce) their propensity to leave a given region. The basic thesis of the present article is then that youth policy can render regional policy tools more effective, with spatial justice restored to a considerable extent, and sufficiently to arrest the trends towards depopulation present in ERB. Ultimately, by shifting young people's propensities from 'leave' mode to 'stay', public policy would affect migration decisions, in such a way that more people remain in a region.

The flight of young people shows how different areas vary greatly in terms of their spatial appeal to them. Against that background, the context of spatial justice that has been analysed here juxtaposes needs and opportunities for implementation by the young generation, and indications as to which imbalances in the area under study actually encourage a decision to move out. The spatial injustice thus alluded to reflect the inability of a local space to offer opportunities of sufficient quantity and quality to meet inhabitants' needs.

\section{The scale of depopulation in ERB}

The issue of depopulation in the EU's formerly communist countries has received wide-ranging discussion in literature on demography, as well as that concerning regional development. The first observation relevant to that concerns the way in which, notwithstanding the $\mathrm{EU}$ accessions of 8 of these states in 2004 (as followed later by Romania, Bulgaria and finally Croatia), major economic differences have continued to pertain between the 'old Union' and the 'new Union'. Diverse disparities can be perhaps best and most powerfully summed up when it is simply recalled that nominal wage-levels between these different parts of Europe continue to differ across a 3-5-fold range.

In reference to the Baltic Sea Region, a 2016 study within the context of VASAB ${ }^{2}$ presented the reduction in population occurring in former communist countries, and setting that against contemporaneous population growth in Sweden and Denmark. A study with the telling title 'Shrink-

${ }^{2}$ VASAB (Vision and Strategies Around the Baltic Sea) entails intergovernmental, multilateral co-operation among 10 countries of the Baltic Sea Region in the field of spatial planning and development (https://vasab.org/). 
ing Regions in a Shrinking Country: The Geography of Population Decline in Lithuania 2001-2011' (Ubarevičienè, van Ham, \& Burneika, 2014) in turn documents a 17.2\% decrease in the population of Lithuania between 1989 and 2011. The authors also observed that the population of Lithuania was shrinking fastest in rural areas and in towns, only still growing in the vicinities of the three major cities of Vilnius, Kaunas and Klaipeda.

Using a standard migration model, Lamberty (2015) observed the relationships between migratory movements and economic ties, quality of governance, the social environment and demographic factors that vary in their significance. In his study summarising the Baltic states' twenty years of independence, Kramer (2012) reported the noteworthy fact that depopulation largely affected the national minorities living in the countries, with Lithuanians, Latvians or Estonians only involved to a much lesser degree. Thus, through depopulation, the share of the population of Latvia declaring itself Latvian increased from $52 \%$ to $60 \%$ in the years $1990-2011$. At the same time, the share of people of Estonian origin in Estonia increased to over 68\% (from 62\%), while Lithuanians in Lithuania passed the $84 \%$ mark (having been at a level of $79 \%$ ). The increase in the aforementioned cases most probably related to job access in the public sector, an aspect proving far more problematic for national minorities, as these emigrate at a faster rate than indigenous peoples, given ethnic conflict that is present.

Poland has also come under strong depopulation pressure, with more than 2.5 million Poles (6.8\% of the population) - mostly of lesser age, leaving the country between 1990 and 2015. In Russia's Kaliningrad District it was only a relocation of war refugees from eastern Ukraine that saved the demographic situation. Otherwise depopulation would have been observable in that region too.

\section{Axes to the empirical research being carried out on youth out-migration}

While numerous empirical research projects have been pursued to explain why young people decide to leave their rural home towns, only a fraction of the extensive relevant literature is addressed here. The first two examples concern prospective migrants, with Baláž, Williams and Fifeková (2016) examining decision weights for different attributes of potential destination countries within a sample of 157 young people (and therefore potential migrants) in Slovakia. They found that, although wages and costs were the dominant attributes, remaining explanatory factors were of a non-economic nature, relating to health and crime, as well as personal freedom and security. Baláž and Williams (2018) in turn drew on data for 540 young participants from 9 EU member states to consider propensity to migrate in relation to principles of uncertainty. A sharp rise in unemployment rates was found to be more disruptive than the introduction of work permits.

Structured interviews are often used to address matters of relevance to actual migrants who have crossed a border. A relevant project here was 'Journeys to Europe' (Hagen-Zanker \& Mallett, 2016), whose interviews dealt with decision-making patterns among Africans who had actually undertaken migrations. It was observed that personal security was joined by economic factors among the main drivers of youth out-migration.

Where immediate research input is essential, public authorities sometimes commission literature reviews and seek to have migration factors arranged in hierarchies in terms of their importance. One such example was the so-called Rapid Evidence Assessment (REA) used by Cummings, Pacitto, Lauro and Foresti (2015). The REA sought to examine the state and level of knowledge on 
drivers of irregular migration to Europe in the context of the 2015 crisis in the Mediterranean. A semi-systematic literature review was conducted in that context, with primary and secondary research studies drawn on in the process.

Some kind of systematisation in the interests of broader perspective is indeed required, given the great number of possible migration factors. Skoglund (2018) provides an example, with a listing of 120 indicators to be taken account of - at least potentially - as youth out-migration is analysed. Kureková (2014) evaluated the relative importance of structural issues, the labour market, and factors at the level of the individual, in affecting the migration choices made by highly-educated young people. In turn, an interesting proposal for how to schedule migration factors by reference to the macro-, meso- or micro-levels was advanced by Kuhnt (2019), whose structured overview discussed the relative importance of different migration factors where various forms of migration were concerned.

Young people's departure from the rural areas present in developed countries has also been a key issue in the literature. Drawing on Norwegian examples, Rye (2011) found that the social backgrounds among the rural young do more to influence migration decisions than contemporary rural migration research has hitherto acknowledged. Heading in the same direction is research by Grassmueck, Goetz and Shields (2008) that rejects an existing (Brookings) concept, to the effect that fragmentary local-governments policy in Pennsylvania was what forced the departure of young people from rural areas there. In fact, it is not bad policy but the 'beaten path effect' that is seen to prevail as routes for rural out-migration are traced.

The very extensive research into youth migration out of developing countries includes the cases of Ecuador, Mexico and Peru (Cazzuffi \& Fernández, 2018), The Philippines (Manalo IV \& van de Fliert, 2013) and Lebanon (Dibeh, Fakih \& Marrouch, 2017). What are mostly explored in these cases are the reasons for young people to move out of rural townships, with further consideration given to benefits and costs for both migrants and the rural areas affected, as well as the factors stimulating young people to either return to or stay in a given region.

Overall, and notwithstanding the many types of research into youth migration (and the wide range of methods, sources and types of scope involved), very little focus on potential migration and future decision factors has actually been achieved. Recent research has dealt predominantly with the decisions of actual migrants, and hence cases in which gained knowledge is no longer in a position to influence decisions made. It was thus the aim of the authors here to take the opposite approach, by exploring future life plans of young people, given that out-migration may be one of several possible tools applied in respect of personal-goal achievement, and not necessarily the one of greatest importance.

\section{The spatial-justice framework underpinning the research}

The so-called spatial justice has an important role to play where the future plans of young people are concerned. It was Soja $(2009$, p.2) who proposed a precise definition for this concept, holding that: 'In the broadest sense, spatial (in)justice refers to an intentional and focused emphasis on the spatial or geographical aspects of justice and injustice. As a starting point, this involves the fair and equitable distribution in space of socially valued resources and the opportunities to use them.' A necessary focus on spatial inequalities was emphasised by Okrasa (2018), who considered the key reasons for this to be thematic and methodological. In the first group, the author included theoretical premises, mainly in the field of the economic sciences, as well as pragmatic considerations relating to development policy and aid allocation. The methodological reasons in turn reflected a significant increase in numbers of studies concerned with spatial inequalities. 
These inequalities have indeed been much-studied, with a multi-faceted approach taken. Kim (2008) sees them as reflecting a balance between two opposite local-development trends, i.e. geographical concentration or distraction. For their part, Connelly and Bradley (2004) focused on two spatial aspects of EU policies, i.e. the distribution of quality and the extent to which elements of spatial injustice are at odds with promoted spatial concepts. Philippopoulos-Mihalopoulos (2014) criticised an excessively technocratic view of spatial justice, advocating in its place the development of a movement to negotiate solutions not foreseen by law. Bassett (2013) suggested that spatial inequality should be addressed by solutions that create bridges of solidarity within existing differences, with a view to existing spatial injustices being reconfigured. Despite extensive discussion among scholars on spatial inequalities and the building of spatial justice, the issue remains unresolved, and in need of applicable solutions.

\section{Depopulation trends in selected areas of ERB}

Results illustrating recent changes in population in the surveyed counties or districts are presented in Table 1.

The population of Bartoszyce County declined by $7.3 \%$ over a 16 -year period. The Słupsk City experienced an even greater decrease, of $8.9 \%$, though almost that entire percentage was absorbed by the area adjacent to the city, which proves attractive to inhabitants seeking better housing conditions in a pleasant coastal area. However, in Lithuania's Klaipeda District, the population fell by approximately $17.7 \%$ in the years $2001-2019$ - a circumstance that reflects quite faithfully the true demographic trends in Lithuania - as confirmed in many publications.

In Sweden's Kalmar County, population size stagnated for the first 10 years of the $21^{\text {st }}$ century, before displaying a $3.9 \%$ increase over the following 9 years. Further data show that almost the whole of this increase was down to events in 2016-2018, i.e. the absorption of a wave of war- and economic refugees mainly originating in the Middle East and Africa.

Quite interesting demographic trends characterised the Russian Federation's Kaliningrad District in the years 2002-2019. While Gusiew only recorded a stable population, the attractive tourist town of Svetlogorsk witnessed an increase in numbers of people by as much as $22.6 \%$. This could be set against the figure for Kaliningrad District as a whole, which is $+4.9 \%$. However, this region has been receiving immigrants from other parts of the Federation, as well as refugees - mainly from regions of eastern Ukraine impacted upon by the civil war.

Table 1. 2000-2019 ERB depopulation trends as revealed by selected territorial units

\begin{tabular}{|c|c|c|c|c|c|}
\hline \multirow{2}{*}{ Country } & \multirow{2}{*}{ Administrative unit } & \multicolumn{3}{|c|}{ Census-based population estimate } & \multirow{2}{*}{$\begin{array}{l}\text { Percentage change } 2019 \\
\text { in relation to } 2002\end{array}$} \\
\hline & & $2002 *$ & $2011 * *$ & $2019 * * *$ & \\
\hline \multirow{4}{*}{ Poland } & Bartoszyce County & 62,492 & 61,288 & 57,916 & -7.3 \\
\hline & Słupsk (City with County Status) & 99,943 & 95,882 & 91,007 & -8.9 \\
\hline & Słupsk County & 91,617 & 96,648 & 98,816 & 7.9 \\
\hline & Total (Słupsk City and County) & 191,560 & 192,530 & 189,823 & -0.9 \\
\hline Lithuania & Klaipeda District & 386,129 & 340,047 & 317,742 & -17.7 \\
\hline Sweden & Kalmar District & 235,391 & 233,536 & 244,670 & 3.9 \\
\hline \multirow{3}{*}{ Russia } & Gusiew County & 37,461 & 37,142 & 37,435 & -0.1 \\
\hline & Svetlogorsk County & 15,196 & 14,875 & 18,633 & 22.6 \\
\hline & Kaliningrad District & 955,281 & 941,873 & $1,002,187$ & 4.9 \\
\hline
\end{tabular}

*2000 - Sweden, 2001 - Lithuania; ** 2010 - Sweden and Russia; *** 2018 - Poland and Sweden.

Source: authors' own elaboration based on https://www.citypopulation.de/. 
Table 2. Age structure (\%) in the surveyed administrative units in 2019*

\begin{tabular}{|l|l|c|c|c|}
\hline \multirow{2}{*}{ Country } & \multicolumn{1}{|c|}{ Administrative unit } & \multicolumn{3}{c|}{ Ages } \\
\cline { 3 - 5 } & & $\mathbf{0 - 1 7}$ yo & $\mathbf{1 8 - 6 4}$ yo & $\mathbf{6 5 + \text { yo }}$ \\
\hline \multirow{3}{*}{ Poland } & Bartoszyce County & 17.4 & 66.2 & 16.4 \\
\cline { 2 - 5 } & Słupsk (City with County Status) & 16.0 & 63.4 & 20.6 \\
\cline { 2 - 5 } & Słupsk County & 19.4 & 66.3 & 14.3 \\
\hline \multirow{2}{*}{ Lithuania } & Klaipeda District & 18.9 & 61.9 & 19.2 \\
\hline Sweden & Kalmar District & 19.8 & 55.5 & 24.7 \\
\hline
\end{tabular}

* 2018 - Poland and Sweden.

Source: authors' own elaboration based on https://www.citypopulation.de/.

Overall, the data presented reveal that, while regions in Sweden and the Russian Federation have recorded slight increases in population over the more-or-less 20-year period, areas in Poland and Lithuania have continued to lose inhabitants. Table 2 presents the age structure of populations in some of the counties or districts surveyed, in terms of percentages of the population remaining in the professionally-active age groups ${ }^{3}$.

Bartoszyce and the area around Słupsk are still characterised by the lowest shares accounted for by people of post-productive age. In contrast, over $20 \%$ of the population in the Słupsk City falls into this category. In Klaipeda District, that share exceeds 19\%, while in Sweden's Kalmar District the rate is as high as $24.7 \%$. The Swedish study area is thus most affected by ageing of the population, and this may help account for its greater willingness to accept immigrants on a permanent basis. The population structure there is nevertheless least favourable, given the lowest observed percentage of people who are of the typical ages associated with professional activity. The indicators to be noted for Poland are still the best. However, the Swedish data may serve as pilot indicators of the fates of other parts of the ERB, with a likelihood that the Polish and Lithuanian localities may follow suit in the near future.

These observations may be summed up as showing clear trends towards depopulation in the Polish and Lithuanian administrative units, as opposed to increases in population in the studied areas of Sweden and Russia, even as the ageing process is emphasised very strongly in the former. Though imperfect, the statistics are clear in suggesting that, should current trends in ERB continue, depopulation will be ongoing.

\section{Research methodology}

A Local Follow-up of Youth Policy survey (LUPP) is an instrument aimed at diagnosing the situations faced by young people in Sweden, and learning more about their plans. Research based on the LUPP methodology (as developed by the Swedish Agency for Youth and Civil Society - MUCF) was run between 2003 and mid-2017, in 177 municipalities around Sweden, i.e. more than half of the total (Onsbacke \& Ambumsgård, 2017). Attempts were made to extend the Swedish survey to countries of Central Europe and Africa (specifically South Africa). The MUCF has drafted a standard questionnaire that can nevertheless be modified and re-shaped by users (municipalities). The main policy goal following on from the surveying is to help units of administration at local or regional level (especially with rural or peripheral locations) to design policy tools capable of attracting young inhabitants, convincing them into staying, or at least encouraging them to return after a period away. LUPP is a voluntary tool that municipalities are under no obligation to use. However, where they are deployed, surveys ought to be carried out every 2-3 years.

\footnotetext{
${ }^{3}$ The table does not include the studied counties in Russia (as no data are available).
} 
When a municipality decides to participate, it receives a set of materials and information on possible analysis. Numerous seminars and meetings take place to disseminate the LUPP methodology among new councillors and officials. The MUCF is responsible for the development of the surveys, while individual municipalities run them, and disseminate the results in the municipality. They also pursue youth policy based on knowledge derived from those results. In Sweden, the surveys are organised in relation to the 13-16, 16-19 and 19-25 year age groups. They are run online, with students able to respond from home or classroom. There are no special requirements as regards survey representativeness, though each participating municipality should assess the size of a study. Where small rural municipalities are concerned, a typical number of respondents would be 150-200, as compared with 1000+ in larger localities. One of the very few publications on LUPP application concerns Sweden (Dalin, Bostedt \& Blusi, 2013). Graduates were studied for their motivations to remain in rural areas of the Mid Sweden Region, which is characterised by declining school-performance scores and a high level of out-migration.

Under the CASYPOT project, research based around the LUPP questionnaire was carried out in six administrative units from four countries, i.e. Słupsk and Bartoszyce in Poland, Klaipeda in Lithuania, Gusiew and Svetlogorsk in Russia's Kaliningrad District, and Emmaboda in Sweden's Kalmar District. An international team of scientists from Sweden, Poland, Russia and Lithuania (the Universities of Vaxjo, Klaipeda and Gdańsk) were involved, and they produced modifications in the questionnaire, albeit not involving more than $10 \%$ of the questions (the aim being adaptation to the specifics of given participant countries not entailing an overall change of scope).

The selection of six participating administrative units followed recruitment from among those in ERB in general, on the basis of criteria relating to location (rural or peripheral), and in line with willingness to adopt survey results as an element of development policy at the level of the unit. While each are collaborated with the project team in designating schools to be surveyed, the last word lay with the former. The study was participated in by high school students, of which the vast majority were aged 16-19. In Bartoszyce, as well as Gusiew and Svetlogorsk, some participants were slightly younger (aged 15 or even 14). The Swedish approach maintained that such young people do begin to shape their life-plans, to the extent that a knowledge of their intentions may serve as a diagnostic tool in respect of the further pursuit of development policy at local level.

A total of 1880 students took part in the study, including 700 from Słupsk, 189 from Bartoszyce, 404 from Klaipeda, 276 from Gusiew, 99 from Svetlogorsk and 212 from Emmaboda. Scales of the different surveys reflected municipalities' organisational possibilities, and - while group sizes differed - the population potentials of the units of administration under study varied greatly anyway (see Table 1).

The research team has not claimed to arrive at research conclusions for the surveyed areas' entire upper secondary school populations, but only for those in groups that chose to participate. Despite this reservation, the survey results represent a very valuable source of collected data on youth preferences as regards the future.

One of the study's main questions concerned the relevance of factors related to the place of residence liable to prompt either departure or an ongoing presence. To that end, the questions resorted to were: How important are the following aspects of the decision to leave/to stay in the area in which you reside? The aspects (or decision-making factors) in question were capable of being assigned to groups relating to:

1. career and material circumstances (the situation in the locality as regards work, continuing education, housing, and the environment in which to raise children);

2. recreation, proximity to nature and proximity to city life; 
3. the social environment and identity (presence of a friend/girlfriend/boyfriend/partner; presence of family; opportunity to be who you really are).

Pupils were able to indicate the importance of these various decision-making factors. Further, to facilitate the development of a synthetic measure of the importance of individual factors, values from 0 to 100 were adopted (not important - 0, slightly important - 20, moderately important 50 , important -80 , very important -100 and unknown -0 ). Individual qualitative determinations were assigned such values by way of discussion among members of the auctorial team (the socalled expert method).

It is worth emphasizing the exclusion from further analysis of the 'don't knows' - i.e. those who answered 'unknown'. This is to say that the synthetic value for the factor's importance was calculated, with no account taken of responses failing to take up a specific position.

The $\mathrm{SMW}_{i o}$ synthetic measure of importance (weighted arithmetic average) used to assess decision factors in regard to departure from an area was given by:

$$
S M W_{i o}=\frac{a i_{10} * X_{i 10}+a i_{20} * X_{i 20}+\ldots+a_{n o} * X_{i n o}}{N}
$$

where:

$S M W_{i 0}$ is the aforesaid synthetic measure of the importance of decision factor $i$ as a given place of residence is departed from;

$a_{n o}$ is the numerical value assigned to the qualitative assessment of the decision factor, equal to 0 , $20,50,80$ or 100 , depending on the accepted qualitative valuation;

$X_{i n o}$ is the frequency of occurrence of responses for the $i$-th decision factor and the $n$-th variant of the qualitative assessment;

$N$ is the number of responses not deviating from the qualitative assessment (not including the answer 'unknown').

To calculate the synthetic measure for the importance of decision factors when it comes to a person staying on in a particular area, use was made of an analogous formula for the $\mathrm{SMW}_{i p}$ (weighted arithmetic average), i.e.:

$$
S M W_{i p}=\frac{a i_{1 p} * X_{i 1 p}+a i_{2 p} * X_{i 2 p}+\ldots+a_{n p} * X_{i n p}}{N} * 100
$$

A synthetic measure of the importance of a decision factor as a given area is left or remained in is represented by the average level of significance respondents assign, where 100 stands for maximum validity while 0 is not valid. The importance of individual factors in individual municipalities may be assessed in this way.

The authors propose the following interpretation of differences in synthetic measures of the importance of the same decision factor as a place is left or as a home town is remained in. Where $\mathrm{SMW}_{i 0}=\mathrm{SMW}_{i p}$, respondents are equally willing to either leave or stay in a given area, should the problems with a given decision-making factor be resolved. Where $\mathrm{SMW}_{i 0}>\mathrm{SMW}_{i p}$, respondents are more inclined to leave a given place than to stay, even if the problems with a given decision-making factor have actually been resolved. Likewise, when $\mathrm{SMW}_{i 0}<\mathrm{SMW}_{i p}$, respondents are less inclined to leave than to remain in a given area, even should the problems of the external environment relating to a given decision-making factor be solved.

For a full analysis, it is worth proposing a formula for calculating deficits or surpluses of potentials, especially in relation to synthetic measures. The first formula is the absolute measure:

$$
A R P_{i}=S M W_{i p}-S M W_{i 0},
$$

where $\mathrm{ARP}_{i}$ is the absolute potential difference in decision factor $i$. 
The $A R P_{i}$ result shows how the level of importance (on a scale from -100 to 100) of the synthetic index for remaining in an area is higher then, lower than or equal to the synthetic index for leaving. Decision factors can be ranked in line with their levels of deficit or surplus, with positive values pointing to a more marked tendency to remain, while negative values indicate a greater tendency to leave.

Another measure of the potential difference is relative, known as relative potential difference, with this counting the value of the absolute measure of the difference in potentials in relation to the synthetic measure characterising the situation as an area is left, in respect of the $i$-th decision-making factor $\left(\mathrm{WRP}_{i}\right)$. The result of the quotient in this respect is multiplied by 100 in the interests of greater transparency in use.

$$
W R P_{i}=\frac{S M W_{i p}-S M W_{i o}}{S M W_{i o}} * 100
$$

The result for $\mathrm{WRP}_{i}$ points to the strength of the relationship between the differences among synthetic indicators and the initial value of the indicator as an area is left. Negative values show the level of the potential deficit in relation to the indicator as an area is left, while positive values show the level of the excess potential in relation to the indicator as an area is left.

\section{Young people's future preferences - results}

To facilitate analysis, the results obtained are presented in a percentage relation to the total. A typical descriptive analysis of social statistics was used. The first question was about what respondents would most like to do after high school.

Overall observations regarding the personal futures of young people from smaller (rural) areas point to a difference between the formerly-communist countries and Sweden, in that the preference for continuing in education is high in the former, but relatively low in the latter. Russian municipalities noted the highest results in this case, attesting to very high-level educational aspi-

Table 3. Expectations for the selection of an occupation following graduation from high school

\begin{tabular}{|l|c|c|c|c|c|c|}
\hline \multirow{2}{*}{$\begin{array}{c}\text { Question: What will you probably do } \\
\text { after leaving high school? }\end{array}$} & \multicolumn{7}{|c|}{$\begin{array}{c}\text { Percentage of respondents } \\
\text { (PL) }\end{array}$} & $\begin{array}{c}\text { Bartoszyce } \\
\text { (PL) }\end{array}$ & $\begin{array}{c}\text { Klaipeda } \\
\text { (LT) }\end{array}$ & $\begin{array}{c}\text { Gusiew } \\
\text { (RU) }\end{array}$ & $\begin{array}{c}\text { Svetlogorsk } \\
\text { (RU) }\end{array}$ & $\begin{array}{c}\text { Emmaboda } \\
\text { (SE) }\end{array}$ \\
\hline Higher education in own country & 31 & 55 & 28 & 50 & 53 & 25 \\
\hline Higher education abroad & 10 & 5 & 21 & 20 & 25 & 3 \\
\hline Work in own town or neighbourhood & 8 & 5 & 9 & 3 & 9 & 18 \\
\hline Work in own country & 6 & 3 & 3 & 5 & 0 & 6 \\
\hline Work abroad & 10 & 6 & 10 & 5 & 0 & 6 \\
\hline Work on farm or in family business & 2 & 1 & 1 & 1 & 0 & 0 \\
\hline $\begin{array}{l}\text { Matching higher education and } \\
\text { professional work }\end{array}$ & 10 & 8 & 8 & 3 & 0 & 6 \\
\hline Starting up own business & 4 & 4 & 2 & 1 & 2 & 3 \\
\hline Travelling & 4 & 4 & 2 & 5 & 0 & 14 \\
\hline Other & 3 & 3 & 3 & 4 & & 1 \\
\hline Unknown & 6 & 8 & 12 & 3 & 5 & 11 \\
\hline
\end{tabular}

Source: CASYPOT project and authors' own estimates. 
Table 4. Intention to move out of the area of residence

\begin{tabular}{|l|c|c|}
\hline \multirow{2}{*}{$\begin{array}{l}\text { Question: Do you think you will move } \\
\text { out of the area you reside in currently? }\end{array}$} & \multicolumn{2}{l|}{ Percentage of respondents } \\
\cline { 2 - 4 } Słupsk (PL) & 79 & 21 \\
\hline Bartoszyce (PL) & 90 & 10 \\
\hline Klaipeda (LT) & 71 & 29 \\
\hline Gusiew (RU) & 75 & 25 \\
\hline Svetlogorsk (RU) & 65 & 35 \\
\hline Emmaboda (SE) & 85 & 15 \\
\hline
\end{tabular}

Source: CASYPOT data.

rations. This may also denote a rather high likelihood of the enclave being left for the purposes of study abroad (as it is the Russian localities in which the clearest preferences for that are to be noted). Swedish pupils are most likely to want to take up work after school, while the least likely are their counterparts from the small urban centres in remaining countries. However, the tendency appears to be more marked in such medium-sized cities as Klaipeda and Słupsk.

A situation in which work and studies are combined applies most to young people from Poland and Lithuania, most probably in line with the opportunities available in this respect. The clear tendency for young Swedes to travel is very symptomatic. In another part of the study, it emerges that more than half of young Swedes started working while still at high school, and have been in a position to save some money. People in Sweden reaching the age of majority become independent, with this usually denoting that they take up a job. In contrast, in the countries of the former communist bloc, parents need to go on supporting their offspring for longer, ensuring that decisions to leave the family home are only typically made at a later stage. Most often, the delay also reflects low salaries available to young people in the formerly communist countries.

The relatively limited tendency for young people in Emmaboda (Sweden) to continue with their education may reflect the way in which working students are able to cover most or all of their living costs out of their salaries. The situation in Poland is the converse, given the way young people in smaller towns start work on the minimum wage.

The next question thus asked respondents to say if they did or did not intend to move out of the area of residence (Table. 4). The majority of young people from the small centres declared themselves ready to leave their towns; and this response would not seem to reflect the scarcity or lack of educational institutions alone. By far the highest percentages willing to leave resided in Bartoszyce and Emmaboda, which are both located very peripherally within their regions. Elsewhere, willingness to leave was again clear, with the lowest figure nevertheless characterizing Svetlogorsk - a well-known seaside resort. Yet, even there, some $65 \%$ of respondents were ready to leave, with the secure conclusion therefore being that young people in these small centres are very much inclined to move from their home towns in search of better opportunities for development.

The obtained results were analysed in a collective group called 'career and material life factors', which included such decision-making factors as: work, continuing education, local housing situation, and environment for raising children. It was expected that these economic factors would be most important to young people (Table 5). ${ }^{4}$

\footnotetext{
${ }^{4}$ The authors verified the statistical significance to the equality of two means in relation to synthetic measures for leaving $\left(\mathrm{SMW}_{i 0}\right)$ and for staying $\left(\mathrm{SMW}_{i p}\right)$. The $\mathrm{H}_{0}$ hypothesis, that the two means are equal, was rejected in relation to continuation of education $(\alpha=0.01)$, work $(\alpha=0.05)$, proximity to city life $(\alpha=0.10)$, proximity to nature $(\alpha=0.10)$, and family and relatives $(\alpha=0.01)$. In other dimensions, there was no basis for rejection of the hypothesis on the equality of means.
} 
Table 5. Factors influencing the decision to leave or stay in a municipality: career and material factors

\begin{tabular}{|c|c|c|c|c|c|}
\hline $\begin{array}{l}\text { How important are the } \\
\text { following aspects of a } \\
\text { decision to leave or stay in } \\
\text { the area in which you live? }\end{array}$ & $\begin{array}{c}\text { Unit of } \\
\text { administration }\end{array}$ & $\mathrm{SMW}_{i o}$ & $\mathrm{SMW}_{i p}$ & $\begin{array}{c}\text { ARP }_{i} \\
\text { Deficit }(-) \text { surplus } \\
(+) \text { of potential }\end{array}$ & $\begin{array}{c}\text { WRP }_{i} \\
\text { Relative difference } \\
\text { of potentials }\end{array}$ \\
\hline \multirow{7}{*}{ Continuation of education } & Słupsk & 66.5 & 54.5 & -11.9 & -18.0 \\
\hline & Bartoszyce & 85.8 & 53.5 & -32.3 & -37.6 \\
\hline & Klaipeda & 66.2 & 54.9 & -11.3 & -17.0 \\
\hline & Gusiew & 61.6 & 46.5 & -15.1 & -24.5 \\
\hline & Svetlogorsk & 75.1 & 64.7 & -10.3 & -13.7 \\
\hline & Emmaboda & 71.9 & 61.5 & -10.4 & -14.5 \\
\hline & AVERAGE & 71.2 & 55.9 & -15.2 & -20.9 \\
\hline \multirow{7}{*}{ Work } & Słupsk & 77.2 & 62.6 & -14.6 & -18.9 \\
\hline & Bartoszyce & 86.8 & 59.9 & -26.9 & -31.0 \\
\hline & \begin{tabular}{|l|} 
Klaipeda \\
\end{tabular} & 60.6 & 55.6 & -4.9 & -8.2 \\
\hline & Gusiew & 59.1 & 44.9 & -14.1 & -23.9 \\
\hline & Svetlogorsk & 59.5 & 50.3 & -9.2 & -15.4 \\
\hline & Emmaboda & 79.9 & 70.2 & -9.7 & -12.1 \\
\hline & AVERAGE & 70.5 & 57.3 & -13.2 & -18.3 \\
\hline \multirow{7}{*}{ Housing situation } & Słupsk & 55.8 & 51.8 & -4.0 & -7.2 \\
\hline & Bartoszyce & 59.9 & 44.8 & -15.1 & -25.2 \\
\hline & Klaipeda & 58.3 & 60.2 & 1.9 & 3.2 \\
\hline & \begin{tabular}{|l|} 
Gusiew \\
\end{tabular} & 41.2 & 56.6 & 15.4 & 37.5 \\
\hline & Svetlogorsk & 35.9 & 43.4 & 7.5 & 20.9 \\
\hline & Emmaboda & 63.3 & 65.8 & 2.5 & 3.9 \\
\hline & AVERAGE & 52.4 & 53.8 & 1.4 & 5.5 \\
\hline \multirow{7}{*}{$\begin{array}{l}\text { Environment for raising } \\
\text { children }\end{array}$} & Słupsk & 51.3 & 48.5 & -2.8 & -5.4 \\
\hline & Bartoszyce & 55.3 & 46.0 & -9.4 & -16.9 \\
\hline & Klaipeda & 58.9 & 53.3 & -5.7 & -9.6 \\
\hline & \begin{tabular}{|l|} 
Gusiew \\
\end{tabular} & 39.4 & 46.9 & 7.6 & 19.3 \\
\hline & Svetlogorsk & 42.5 & 50.4 & 7.9 & 18.6 \\
\hline & Emmaboda & 57.0 & 61.5 & 4.4 & 7.8 \\
\hline & AVERAGE & 50.7 & 51.1 & 0.3 & 2.3 \\
\hline \multirow{7}{*}{ TOTAL } & Słupsk & 250.8 & 217.5 & -33.3 & -13.3 \\
\hline & Bartoszyce & 287.9 & 204.2 & -83.7 & -29.1 \\
\hline & Klaipeda & 244.0 & 224.0 & -20.0 & -8.2 \\
\hline & Gusiew & 201.2 & 195.0 & -6.2 & -3.1 \\
\hline & Svetlogorsk & 213.0 & 208.9 & -4.1 & -1.9 \\
\hline & Emmaboda & 272.1 & 259.0 & -13.2 & -4.8 \\
\hline & AVERAGE & 244.8 & 218.1 & -26.8 & -10.1 \\
\hline
\end{tabular}

Source: authors' own elaboration.

The average ratings for the importance of individual decision-making factors indicate a clear division into two groups, i.e. continuing education and work with importance ratings of around 70 points, as well as local housing situation and the environment for raising children - with average scores slightly above 50 points. Worth emphasising in regard to the results analysed vis-à-vis career opportunities and material life conditions was the relatively most difficult situation of the two Polish areas, i.e. Słupsk (where the total deficit exceeds 13 points), and Bartoszyce (almost 30 points). The situation of the other studied units of administration is noticeably better, with the best 
Table 6. Factors influencing the decision to leave or stay in an area: leisure and personal interests

\begin{tabular}{|c|c|c|c|c|c|}
\hline $\begin{array}{l}\text { How important are the } \\
\text { following aspects of a } \\
\text { decision to leave or stay in } \\
\text { the area in which you live? }\end{array}$ & $\begin{array}{c}\text { Unit of } \\
\text { administration }\end{array}$ & $\mathrm{SMW}_{\text {io }}$ & $\mathrm{SMW}_{i p}$ & $\begin{array}{c}\text { ARP }_{i} \\
\text { Deficit (-) surplus } \\
(+) \text { of potential }\end{array}$ & $\begin{array}{c}\text { WRP }_{i} \\
\text { Relative difference } \\
\text { of potentials }\end{array}$ \\
\hline \multirow{7}{*}{ Recreational interests } & Słupsk & 63.8 & 59.1 & -4.7 & -7.3 \\
\hline & Bartoszyce & 69.6 & 53.2 & -16.4 & -23.6 \\
\hline & Klaipeda & 56.7 & 54.9 & -1.8 & -3.1 \\
\hline & Gusiew & 54.8 & 40.3 & -14.5 & -26.4 \\
\hline & Svetlogorsk & 47.5 & 51.4 & 3.8 & 8.1 \\
\hline & Emmaboda & 63.6 & 61.2 & -2.4 & -3.8 \\
\hline & AVERAGE & 59.3 & 53.3 & -6.0 & -9.4 \\
\hline \multirow{7}{*}{ Proximity to nature } & Słupsk & 37.4 & 42.8 & 5.4 & 14.6 \\
\hline & Bartoszyce & 32.0 & 36.9 & 4.9 & 15.5 \\
\hline & Klaipeda & 49.3 & 49.2 & 0.1 & 0.1 \\
\hline & Gusiew & 28.2 & 45.4 & 17.2 & 61.1 \\
\hline & Svetlogorsk & 25.7 & 41.6 & 15.9 & 62.0 \\
\hline & Emmaboda & 45.0 & 54.3 & 9.3 & 20.6 \\
\hline & AVERAGE & 36.2 & 45.1 & 8.8 & 29.0 \\
\hline \multirow{7}{*}{ Proximity to city life } & Słupsk & 48.3 & 43.8 & -4.5 & -9.3 \\
\hline & Bartoszyce & 57.0 & 43.4 & -13.6 & -23.9 \\
\hline & Klaipeda & 52.9 & 46.5 & -6.4 & -12.1 \\
\hline & Gusiew & 36.0 & 35.4 & -0.7 & -1.8 \\
\hline & Svetlogorsk & 49.2 & 35.8 & -13.4 & -27.2 \\
\hline & Emmaboda & 64.6 & 55.3 & -9.3 & -14.3 \\
\hline & AVERAGE & 51.3 & 43.3 & -8.0 & -14.8 \\
\hline \multirow{7}{*}{ TOTAL } & Słupsk & 149.4 & 145.7 & -3.7 & -2.5 \\
\hline & Bartoszyce & 158.6 & 133.5 & -25.1 & -15.8 \\
\hline & Klaipeda & 158.8 & 150.7 & -8.1 & -5.1 \\
\hline & Gusiew & 119.0 & 121.1 & 2.1 & 1.8 \\
\hline & Svetlogorsk & 122.4 & 128.7 & 6.4 & 5.2 \\
\hline & Emmaboda & 173.2 & 170.8 & -2.4 & -1.4 \\
\hline & AVERAGE & 146.9 & 141.7 & -5.1 & -3.0 \\
\hline
\end{tabular}

Source: authors' own elaboration.

assessed potential being that of Svetlogorsk, a well-known resort town. Detailed analysis of the results in turn emphasises the significant potential deficits in terms of the possibility of continuing education. This means that, for the most part, young people will have to leave if they are to go on with their education.

Analysis of the decision-making factor of work reveals how deficits as regards potential apply to all the area analysed, albeit with the most severe deficits characterising Bartoszyce, Gusiew and Słupsk. A similar situation is observed in relation to continuing education. In this respect, potential deficits in the other areas analysed are several times smaller. In respect of the housing situation (as viewed by young people), it is Gusiew and Svetlogorsk that are seen to have surplus potentials, while the largest deficits concern the two Polish localities. The largest deficit in the environment for raising children characterises Bartoszyce. Surpluses occur in both the Russian and the Swedish units of administration studied, while other areas reveal moderate deficits. 
Moreover, irrespective of study area, a major decision-making factor inducing young people to leave home is the need for them to continue with their education outside their specific town of residence (Table 5). Uncertainty of job prospects is then the second most important factor encouraging young people to leave. For most, the housing situation and the environment for raising children are seen to be lesser factors. Indeed, it is interesting to note how some localities (Russian especially) feature surpluses in potential where these factors are concerned. The least-favourable result from the analysis concerns the Polish areas, especially Bartoszyce, though the situation of Słupsk is also not favorable. All of the areas examined (including Swedish Emmaboda) featured overall deficits in this decision category.

Of the three factors in the group entitled 'leisure and personal interests', the most important is a person's ability to pursue their own recreational interests; with closeness to urban life in second place, and closeness to nature the least preferred. The factor of closeness to city life associated with the largest deficit in terms of potentials, is present in all the localities studied, but is greatest in the cases of Svetlogorsk and Bartoszyce. Deficits elsewhere are smaller. Interestingly, Klaipeda has a deficit of 12.1 points in this respect, which is surprising given the size of that city. Nevertheless, in the view of Lithuania's young people, Klaipeda is not a locality offering an urban life of adequate quality.

In the case of the 'recreational interests' factor, all areas but Svetlogorsk indicate deficits in potentials. These are relatively small in Słupsk, Klaipeda and Emmaboda. Regarding proximity to nature, Klaipeda revealed a balanced potential, while the other examined municipalities had surplus potential. In total, within the broad category of leisure and personal interests, the largest deficit concerns Bartoszyce, and the largest (but fairly moderate) surplus is found in Svetlogorsk. In general, other municipalities have slight deficits, while Emmaboda exhibits a slight surplus. To sum up, most of the areas considered have deficits in potential, and in the capacity to meet recreational needs and the proximity to urban life; while proximity to nature reveals surplus potentials.

While it was earlier questioned whether soft factors in the category of social environment and identity would be significant, the study reveals otherwise. Data in Table 8 confirm that young people in all areas surveyed feel they can count on the support of family if they choose to remain in their home towns (surplus potentials in this respect are recorded in each case). The factor emerges as most important in this category influencing a decision to remain in a given area. The second-most important decision-making factor is then emotional (relating to the presence of a friend, girlfriend or boyfriend, or partner), and this too generated surplus potentials in all of the smaller units of administration but Słupsk. The identity factor was characterised by moderate deficits in the Polish and Lithuanian areas, marked deficits in the Russian areas, and a surplus in the Swedish case. In summary, it was social and personal factors that are found to favour a young person's remaining in each of the areas studied, albeit to varying degrees.

In general, family and emotional factors emerged as influential where migration was concerned, having a clear capacity to keep young people in their native areas. On the other hand, difficulties with the full realisation of a young person's own identity may represent an important factor encouraging departure from a given locality.

Reference to average results allows for the development of a ranking based around calculated arithmetic means for all areas analysed taken together (Table 8). The basis for the ranking is thus provided by the $\mathrm{SMW}_{\text {io }}$ value. 
Table 7. Factors influencing the decision to leave or remain in an area: social environment and identity

\begin{tabular}{|c|c|c|c|c|c|}
\hline $\begin{array}{l}\text { How important are the } \\
\text { following aspects of a } \\
\text { decision to leave or stay in } \\
\text { the area in which you live? }\end{array}$ & $\begin{array}{c}\text { Unit of } \\
\text { administration }\end{array}$ & $\mathrm{SMW}_{i o}$ & $\mathrm{SMW}_{i p}$ & $\begin{array}{l}\text { ARP }_{i} \text { Deficit (-) } \\
\text { surplus } \\
(+) \text { of potential }\end{array}$ & $\begin{array}{l}\text { WRP } \\
\text { Relative difference } \\
\text { in potentials }\end{array}$ \\
\hline \multirow{7}{*}{$\begin{array}{l}\text { Friends or girlfriend/ } \\
\text { boyfriend/partner }\end{array}$} & Słupsk & 66.1 & 65.2 & -0.9 & -1.4 \\
\hline & Bartoszyce & 63.3 & 63.4 & 0.0 & 0.1 \\
\hline & Klaipeda & 58.0 & 61.0 & 3.0 & 5.3 \\
\hline & Gusiew & 47.7 & 57.8 & 10.1 & 21.3 \\
\hline & Svetlogorsk & 45.7 & 62.6 & 16.9 & 36.9 \\
\hline & Emmaboda & 68.1 & 68.9 & 0.8 & 1.1 \\
\hline & AVERAGE & 58.2 & 63.1 & 5.0 & 10.5 \\
\hline \multirow{7}{*}{ Family and relatives } & Słupsk & 62.3 & 65.7 & 3.4 & 5.5 \\
\hline & Bartoszyce & 62.8 & 69.0 & 6.2 & 9.9 \\
\hline & Klaipeda & 61.1 & 64.2 & 3.1 & 5.1 \\
\hline & Gusiew & 57.9 & 71.5 & 13.5 & 23.3 \\
\hline & Svetlogorsk & 60.0 & 73.6 & 13.6 & 22.7 \\
\hline & Emmaboda & 60.1 & 71.6 & 11.5 & 19.1 \\
\hline & AVERAGE & 60.7 & 69.3 & 8.6 & 14.3 \\
\hline \multirow{7}{*}{ Here I cannot be who I am } & Słupsk & 44.1 & 42.1 & -2.0 & -4.6 \\
\hline & Bartoszyce & 48.2 & 42.1 & -6.1 & -12.7 \\
\hline & Klaipeda & 46.5 & 45.9 & -0.6 & -1.4 \\
\hline & Gusiew & 50.9 & 32.4 & -18.5 & -36.4 \\
\hline & Svetlogorsk & 71.2 & 54.3 & -16.9 & -23.7 \\
\hline & Emmaboda & 51.4 & 60.0 & 8.6 & 16.7 \\
\hline & \begin{tabular}{|l} 
AVERAGE \\
\end{tabular} & 52.1 & 46.1 & -5.9 & -10.4 \\
\hline \multirow{7}{*}{ TOTAL } & Słupsk & 172.6 & 173.0 & 0.5 & 0.3 \\
\hline & Bartoszyce & 174.3 & 174.5 & 0.1 & 0.1 \\
\hline & Klaipeda & 165.6 & 171.1 & 5.5 & 3.3 \\
\hline & Gusiew & 156.6 & 161.7 & 5.1 & 3.3 \\
\hline & \begin{tabular}{|l} 
Svetlogorsk \\
\end{tabular} & 176.9 & 190.6 & 13.6 & 7.7 \\
\hline & Emmaboda & 179.6 & 200.4 & 20.8 & 11.6 \\
\hline & AVERAGE & 170.9 & 178.5 & 7.6 & 4.4 \\
\hline
\end{tabular}

Source: authors' own elaboration.

Table 8. Ranking of decision factors underpinning departures from places studied

\begin{tabular}{|l|c|c|c|}
\hline \multicolumn{1}{|c|}{ Decision factor } & $\mathbf{S M W}_{i 0}$ & $\mathbf{S M W}_{i p}$ & ARP $_{i}$ \\
\hline 1. Continuation of education & 71.2 & 55.9 & -15.3 \\
\hline 2. Work & 70.5 & 57.3 & -13.2 \\
\hline 3. Family and relatives & 60.7 & 69.3 & 8.6 \\
\hline 4. Recreational interests & 59.3 & 53.3 & -6.0 \\
\hline 5. Friends or girlfriend/boyfriend/partner & 58.2 & 63.1 & 5.0 \\
\hline 6. Housing situation in the municipality & 52.4 & 53.8 & 1.4 \\
\hline 7. Here I cannot be who I am & 52.1 & 46.1 & -5.9 \\
\hline 8. Proximity to city life & 51.3 & 43.3 & -8.0 \\
\hline 9. Environment for raising children & 50.7 & 51.1 & 0.4 \\
\hline 10. Proximity to nature & 36.2 & 45.1 & 8.8 \\
\hline
\end{tabular}

Source: authors' own elaboration. 
Overall, the ranking of the importance of decision-making factors, expressed as the average score for each area studied, confirms existing observations regarding the significant role of social capital in peripheral areas, reveals a shortage of educational assets and good job opportunities, indicates difficult access to the benefits of urban life such as culture, and points to significant deficiencies where the pursuit of recreational aims is concerned. The only factor that contributes to young people staying where they are is proximity to nature, though this may not be regarded as a particularly important factor.

\section{Conclusions for regional policy in ERB}

Trends towards depopulation characterise the entire euroregion, applying above all to peripheral centres, which young people are tending to leave en masse. The situation in larger cities or urban agglomerations looks slightly more favourable. Initially, the main decision-making factor underpinning out-migration relates to continuation of education, at higher level especially. However, in the fullness of time, it becomes more a matter of local job markets not being able to offer much to highly-educated people, with offers mainly looking suitable in large agglomerations, or abroad.

While regional policy is clearly unable to operate in such a way as to ensure that most young people are retained, a possible reason for this lies in the inadequate response to threats, as is made apparent by the emerging attitudes of young people to the shaping of their futures. A typical regional-policy approach to labour-market problems sees the situation diagnosed for differences between the supply of - and demand for - work entailing specific qualifications, with the attitudes of young people in turn ignored. This leaves policy attempting to redesign labour-supply structure in line with the demand employers have reported, while not taking account of the young generation's life plans. It may actually be this lack of consideration for aspirations that motivates departures among young people.

A focus on the labour market being adapted to the inefficient local economy might thus give way to beneficial redesigning of demand for labour in such a way that greater productivity is assured, with this then creating better prospects for both productivity and wages. There must therefore be a move away from investment in local education for the low-skilled towards increased productivity of the local economy capable of sustaining higher-quality employment and better-salaried positions. As Śleszynski (2018) suggests, regional policy should support the use of endogenous resources, concentrate on internal targets, and - in particular - support the re-investment of local capital. Authors supporting this opinion offer an assessment that youth human capital is currently one of the most valuable resources, given its very high potential to ensure growth. For their part, Bukowski, Koryś and Śniegocki (2017) propose a consolidation of resources and strengthening of functional ties among centres, as a universal principle that should underpin regional policy. In our understanding, investment in youth definitely represents this kind of consolidation of resources, which serves to safeguard human capital against leakage.

An understanding of the importance of decisions to leave and stay, as ranked factor by factor, may facilitate the design of tools suitable for addressing potential deficits. For example, in motivating young people to return to their home towns once they have gained their higher education, use might be made of a set of instruments including funded scholarship programmes, investment grants for local small and medium enterprises to increase productivity and local production volumes, work to revitalise housing and construction programmes involving young people as such, as well as the supported founding of nurseries and kindergartens, playgrounds and places of recreation. 
To some extent, individual areas (or subregions) of ERB are already making use of tools of the kind referred to, most especially in Sweden and in areas appealing most to tourists. Thus, on completing their education, young people from the towns in question are more likely than those elsewhere around the Baltic to make their return. Outsiders are also attracted. In turn, the factor of social ties is very strong in the Kashubian district (a subregion east of Gdansk in Poland). The demographic resilience and local development to be noted there may also serve as an example for many regions of Poland (at least).

In summing up this study's various considerations, it is worth pointing to the following main conclusions, when it comes to elements of youth policy being deployed to ensure more-effective shaping of regional policy.

1. Those seeking to predict a region's demographic and social prospects will find it of value to examine the life preferences of young people who are soon to be school-leavers.

2. If youth preferences are incorporated into regional policy, unfavourable trends as regards depopulation may be counteracted more effectively.

3. Acquaintanceship with young people's specific preferences regarding their future lives is enough to indicate simple and cheap instruments which might rapidly temper inclinations to leave places of residence behind. Spatial development plans also look relevant here, especially where they focus in on the creation of recreational areas in public space.

4. While the main factor prompting a change of residence among the young is a desire to continue with education elsewhere, this can be regarded as a temporary influence capable of being tackled via scholarships operating to increase the likelihood of high-quality work.

5. A factor of great importance encouraging a young person's continued presence in a municipality is the support family can extend. This factor is thus supportive of effective local economic development and benefit, and is capable of being enhanced by further-reaching social integration at local and regional level.

6. A change of labour-market policy that raises the quality of demand can do much to encourage young people to return to their places of origin. Equally, the current model by which labour supply adjusts to inefficient demand (via the low productivity of local enterprises) only serves to further intensify the inefficiency of the local economy.

7. As regional and local policy is shaped, special attention needs to be paid to deteriorating housing stock in small towns - itself a reflection of the population's low levels of income. Publicly-assisted revitalisation and extension of housing with a good standard of living is thus a necessity.

8. Social capital (and especially family and proximity to nature) offer small provincial towns an unquestionable advantage compared with large agglomerations. Regional pro-family policy can further reinforce this, ensuring a maximisation of impact of state activity. Public involvement in caring for the state of nature may in turn attract older people to smaller towns, as well as those seeking to leave large agglomerations for a variety of reasons.

9. The work presented here sustains the thesis that a shaping of regional policy via youth policy can facilitate attainment of goals, above all by helping young people to remain in their native regions.

10. The technical solutions proposed here as regards measurement (determining deficits or surpluses in young people's development potentials) can gain ready application in other LUPPrelated research. 


\section{References}

Baláž, V., \& Williams, A.M. (2018). Migration decisions in the face of upheaval: An experimental approach. Population, Space and Place, 24(1), pp. 13. https://doi.org/10.1002/psp.2115

Baláž, V., Williams, A. M., \& Fifeková, E. (2016). Migration Decision Making as Complex Choice: Eliciting Decision Weights under Conditions of Imperfect and Complex Information through Experimental Methods. Population, Space and Place, 22(1), 36-53. https://doi.org/10.1002/psp.1858

Bassett, S. M. (2013). The role of spatial justice in the regeneration of urban spaces. Groningen: Network of European-United States Regional and Urban Studies Program And Master of Urban Planning Capstone Project, Rijkuniversiteit Groningen - International School of Spatial Policy Studies. Retrieved from https://pdfs.semanticscholar.org/8bf4/a0d1ac4f674a8e8fbcf5fb63e4181c8c3f3b.pdf

Bukowski, M., Koryś, P., \& Śniegocki, A. (2017). Na rozdrożu - polityka regionalna wobec globalnych przemian. Warsaw: Wise Europa.

Cazzuffi, C., \& Fernández, J. (2018). Rural youth and migration in Ecuador, Mexico and Peru. Working Paper Series, 235. Santiago: Centro Latinoamericano para el Desarrollo Rural.

Connelly, S., \& Bradley, K. (2004). Spatial justice. European spatial policy and the case of polycentric development. Proceedings of the ECPR Joint Sessions 2004. Uppsala: ECPR.

Cummings, C., Pacitto, J., Lauro, D., \& Foresti, M. (2015). Why people move: understanding the drivers and trends of migration to Europe. ODI Working paper, 430. London: Overseas Development Institute.

Dalin, R., Bostedt, G., \& Blusi, M. (2013). Ungdomar i Västernorrland-åsikter och attityder. Fou Västernorrland.

Dibeh, G., Fakih, A., \& Marrouch, W. (2017). Decision to Emigrate Amongst the Youth in Lebanon. Discussion Paper Series, 10493. Bonn: Institute of Labor Economics.

Grassmueck, G., Goetz, S., \& Shields, M. (2008). Youth Out-Migration from Pennsylvania: The Roles of Government Fragmentation vs. the Beaten Path Effect. The Journal of Regional Policy and Analysis, 38(1), 77-88.

Hagen-Zanker, J., \& Mallett, R. (2016). Journeys to Europe. The role of policy in migrant decision-making. ODI Insights. Retrieved from https://www.odi.org/sites/odi.org.uk/files/odi-assets/publications-opinion-files/10297.pdf

Kim, S. (2008). Spatial Inequality and Economic Development: Theories, Facts, and Policies. Commission on Growth and Development Working Paper, 16. Washington DC: The World Bank.

Kramer, M. (2012). The Baltic Countries after Two Decades of Independence. Achievements, Setbacks, Internal Challenges. PONARS Eurasia Policy Memo, 200. Retrieved from http://www. ponarseurasia. $\mathrm{org} / \mathrm{sites} /$ default/files/policy-memos-pdf/pepm200.pdf

Kuhnt, J. (2019). Literature review: drivers of migration. Why do people leave their homes? Is there an easy answer? A structured overview of migratory determinants. Discussion Paper, 9/2019. Bonn: Deutsches Institut für Entwicklungspolitik. http://dx.doi.org/10.23661/dp9.2019

Kureková, L. (2014). EU accession and youth labour mobility from Slovakia: labour market perspective. Slovak Governance Institute, Bratislava and Central European University. Budapest: ECPR General Conference. Retrieved from https://ecpr.eu/Filestore/PaperProposal/6cf14694-a363-446b-ab3c-cfc312328d58.pdf

Lamberty, L. (2015). Explaining Baltic Migration After EU Accession: Determinants and Consequences. Retrieved from https://www.ehl.lu.se/media/ehl/snee/papers/lamberty.pdf

Manalo IV, J.A., \& van de Fliert, E. (2013). Push and Pull Factors in Rural Filipino Youth's Outmigration from Agricultural Communities. Asian Journal of Agriculture and Development, 10(2), 1-15. https:// doi.org/10.22004/ag.econ.199418

Okrasa, W. (2016). Przestrzenne aspekty nierówności społecznych: sprawiedliwość przestrzenna a zróżnicowanie dobrostanu lokalnego - ewaluacja wpływu środków rozwojowych [Spatial aspects of social inequality: spatial justice and differentiation of community wellbeing - evaluation of the impact of development resources]. Uniwersyteckie Czasopismo Socjologiczne, 15(2), 25-51. 
Onsbacke, L., \& Ambumsgård, R. (2017). Ett år med Lupp. Mer än en enkät. Stockholm: Myndigheten för ungdoms- och civilsamhällesfrågor.

Philippopoulos-Mihalopoulos, A. (2014). The Movement of Spatial Justice. Mondi Migranti, 8, 1-13. https://doi.org/10.3280/MM2014-001001

Rye, J. F. (2011). Youth migration, rurality and class: a Bourdieusian approach. European Urban and Regional Studies, 18(2), 170-183. https://doi.org/10.1177/0969776410390747

Skoglund, E. (2018). Deliverable 4.1.3. Evaluation report of youth migration indicator including the identification of shortfalls. YOUMIG Project. Retrieved from http://www.interreg-danube.eu/uploads/media /approved_project_output/0001/17/3c56ceb82b0f2612667f818bdfd2a7244ba5dce5.pdf

Śleszyński, P. (2018). Demograficzne wyzwania rozwoju regionalnego Polski [Demographic challenges of regional development of Poland]. Studia KPZK, 183, 225-247.

Soja, E. W. (2009). The city and spatial justice. Justice spatiale, spatial justice, 1, pp. 5. Retrieved from https://www.jssj.org/wp-content/uploads/2012/12/JSSJ1-1en4.pdf

Ubarevičienè, R., van Ham, M., \& Burneika, D. (2014). Shrinking Regions in a Shrinking Country: The Geography of Population Decline in Lithuania 2001-2011. IZA Discussion Paper, 8026. Bonn: Institute of Labor Economics. Retrieved from http://hdl.handle.net/10419/96813

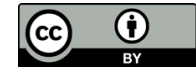

